\title{
THE ART OF OBJECTS
}

The Birth of Italian Industrial Culture, 1878-1928 



\section{LUCA COTTINI}

\section{The Art of Objects}

\section{The Birth of Italian Industrial Culture, 1878-1928}


(C) University of Toronto Press 2018

Toronto Buffalo London

utorontopress.com

Printed in the U.S.A.

ISBN 978-1-4875-0283-6

Printed on acid-free paper with vegetable-based inks.

Toronto Italian Studies

\section{Library and Archives Canada Cataloguing in Publication}

Cottini, Luca, author

The art of objects : the birth of Italian industrial culture, 1878-1928 /

Luca Cottini.

(Toronto Italian studies)

Includes bibliographical references and index.

ISBN 978-1-4875-0283-6 (cloth)

1. Manufacturing industries - Italy - History - 19th century. 2. Manufacturing industries - Italy - History - 20th century. 3. Industries - Italy - History -

19 th century. $\quad 4$. Industries - Italy - History - 20th century. 5. Industrial arts -

Italy - History - 19th century. 6. Industrial arts - Italy - History -

20th century. I. Title. II. Series: Toronto Italian studies

HD9735.I8C68 $2018 \quad 338.40945 \quad$ C2018-900370-7

This book has been published with the assistance of ISSNAF (Italian Scientists and Scholars of North America Foundation), the Subvention of Publication Program of Villanova University, and the Richard and Mary Anne Francisco Endowed Fund for Italian Studies.

University of Toronto Press acknowledges the financial assistance to its publishing program of the Canada Council for the Arts and the Ontario Arts Council, an agency of the Government of Ontario.

Canada Council for the Arts
Conseil des Arts du Canada
ONTARIO ARTS COUNCIL

CONSEIL DES ARTS DE L'ONTARIO

an Ontario government agency

un organisme du gouvernement de I'Ontario
und 
A Te che non ti stanchi di aspettare 
